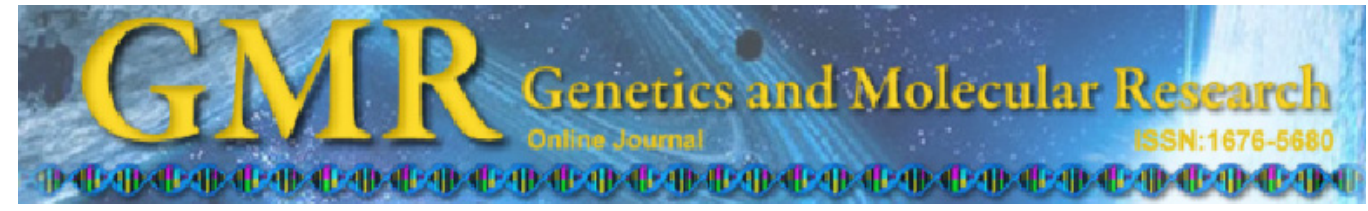

\title{
Population divergence and peculiar karyoevolutionary trends in the loricariid fish Hypostomus aff. unae from northeastern Brazil
}

\author{
J.A. Bitencourt ${ }^{1}$, P.R.A.M. Affonso ${ }^{2}$, L. Giuliano-Caetano ${ }^{1}$, \\ P.L.S. Carneiro ${ }^{2}$ and A.L. Dias ${ }^{1}$ \\ ${ }^{1}$ Departamento de Biologia Geral, Universidade Estadual de Londrina, PR, Brasil \\ ${ }^{2}$ Departamento de Ciências Biológicas, Universidade Estadual do Sudoeste da Bahia, \\ Jequié, BA, Brasil \\ Corresponding author: A.L. Dias \\ E-mail: anadias@uel.br
}

Genet. Mol. Res. 11 (2): 933-943 (2012)

Received January 28, 2011

Accepted November 30, 2011

Published April 13, 2012

DOI http://dx.doi.org/10.4238/2012.April.13.1

\begin{abstract}
Loricariidae (Siluriformes, Hypostominae) is one of the most diverse catfish families. In spite of the wide distribution of loricariids in South America, cytogenetic reports are available for only a few species, mostly from southern and southeastern Brazil. We made the first chromosomal analysis of Hypostomus aff. unae from the Contas River basin in northeastern Brazil. Four populations isolated by short distances but from distinct landscapes were studied based on conventional staining, C-banding, argyrophilic nucleolar organizer regions (Ag-NOR), $\mathrm{CMA}_{3} /$ DAPI fluorochrome staining, and fluorescent in situ hybridization with $18 \mathrm{~S}$ rDNA probes. Although sharing the same diploid number $(2 n=76)$ and NOR locations, each population presented exclusive karyotype formulae and specific patterns of heterochromatic and AT-rich regions. The derived karyotypes of $H$. aff. unae ( $2 \mathrm{n}>54$; high number of acrocentrics bearing AT-rich interstitial heterochromatin) indicated a divergent karyoevolution, mostly driven by centric fissions, pericentric inversions and particular
\end{abstract}


heterochromatin dispersion models. This finding of distinct evolutionary units in $H$. aff. unae will be useful for understanding the natural history of loricariids from relatively unexplored coastal basins in South America.

Key words: Cytogenetics; Biodiversity; Heterochromatin; Fluorochromes; Loricariidae

\section{INTRODUCTION}

Loricariidae is the largest catfish family and the fifth most species-rich group of the 515 recognized fish families (Nelson, 2006) comprising about 710 species and 96 genera (Ferraris Jr., 2007). As expected, loricariids are regarded as a dominant and taxonomically complex freshwater fish group in the Neotropical region (Nelson, 2006). The genus Hypostomus stands out as one of the most abundant and puzzling ones in this family, with approximately 130 species and more species being described every year (Zawadzki et al., 2008).

On the other hand, cytogenetic studies in Neotropical fish have shown a unique genomic plasticity, higher than that of any other vertebrate group (Nirchio and Oliveira, 2006). In fact, chromosomal analyses have been successful in determining the real number of species among morphologically similar (cryptic) forms of several tropical fish groups and evolutionarily significant units (Oliveira et al., 2009a). Unfortunately, little emphasis has been placed on chromosomal variability in conservation genetics, for instance, although cytogenetic analyses cannot be replaced by DNA studies and chromosomal differences often affect fertility (Allendorf and Luikart, 2007).

A remarkable karyotypic variation has been identified within Loricariidae, with diploid numbers ranging from $2 \mathrm{n}=34$ in Ancistrus sp (Oliveira et al., 2009b) to $2 \mathrm{n}=96$ in Upsilodus sp (Kavalco et al., 2005) and quite distinct karyotype formulae. Such diversity suggests that centric fissions and pericentric inversions have played a major role in the karyoevolutionary divergence of this family (Artoni and Bertollo, 2001). Nevertheless, cytogenetic studies in Loricariidae are still scarce and the available data account for only about $17 \%$ of the described species.

Moreover, the cytogenetic reports in fish populations from northeastern basins in South America are incipient when compared to other regions, in spite of their threatened and endemic fauna (Jacobina et al., 2009). Thus, in the present study, we provide the first cytogenetic analysis in populations of a loricariid species (Hypostomus aff. unae Steindachner, 1878) from coastal rivers in northeastern Brazil and infer about the trends of chromosomal evolution within the genus and the family as well.

\section{MATERIAL AND METHODS}

Forty-six specimens of $H$. aff. unae from the Contas River basin, Bahia, northeastern Brazil, were analyzed: 3 males, 2 females and 5 juveniles from the main channel of the Contas River $\left(13^{\circ} 51^{\prime} 51^{\prime \prime} \mathrm{S} / 40^{\circ} 04^{\prime} 54^{\prime \prime} \mathrm{W}\right), 6$ males, 1 female and 3 immature specimens from the Preto do Costa River $\left(13^{\circ} 45^{\prime} 84^{\prime \prime} \mathrm{S} / 39^{\circ} 56^{\prime} 47^{\prime \prime} \mathrm{W}\right), 9$ males and 6 juveniles from the Oricó River $\left(14^{\circ} 08^{\prime} 03^{\prime \prime} \mathrm{S} / 39^{\circ} 21^{\prime} 30^{\prime \prime} \mathrm{W}\right)$, and 4 males, 4 females and 3 juveniles from the Preto do Criciúma River (13 $\left.55^{\prime} 45^{\prime \prime} \mathrm{S} / 39^{\circ} 57^{\prime} 57^{\prime \prime} \mathrm{W}\right)$ (Figure 1). These populations were correspondingly named A, B, C, and D. Collection sites B, C, and D are about 17, 80 and $6 \mathrm{~km}$ apart from the collection site in the Contas River (site A), respectively. Voucher specimens were identified by Dr. 
Claudio Zawadski (UEM) and deposited in the ichthyological collection at the Universidade Estadual de Maringá (UEM - NUPELIA), PR, Brazil (NUP 9811, 9814).

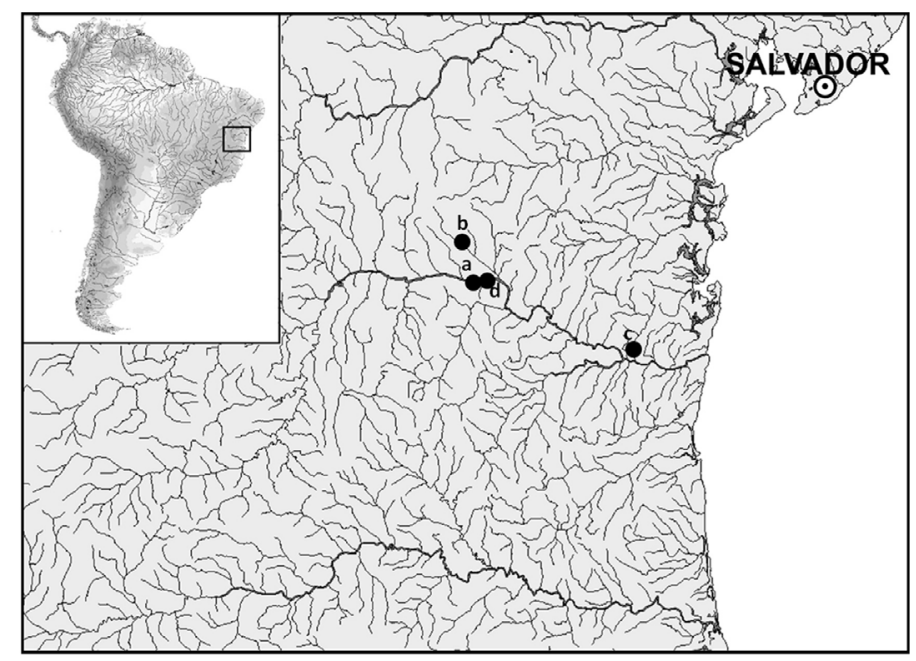

Figure 1. Map of the Contas River basin in Bahia State, Brazil, northeastern South America, indicating the collection sites of Hypostomus aff. unae. Contas River (a), Preto do Costa River (b), Oricó River (c), and Preto do Criciúma Stream $(\mathbf{d})$.

Mitotic chromosomes were obtained from kidney cells according to Bertollo et al. (1978) after mitotic stimulation using a commercial bacterial and fungal antigen (Munolan ${ }^{\circledR}$ ) as proposed by Molina (2001). The chromosomes were classified as: metacentric (m), submetacentric (sm), subtelocentric (st), and acrocentric (a), as elsewhere described in fish cytogenetics (Artoni and Bertollo, 2001; Alves et al., 2006). The fundamental arm number (FN) was calculated taking into account that $\mathrm{m} / \mathrm{sm}$ chromosomes are bi-armed and st/a chromosomes are uni-armed.

The nucleolar organizer regions (NORs) were detected by silver nitrate staining (Howell and Black, 1980) and fluorescent in situ hybridization (FISH) (Pinkel et al., 1986) with slight modifications. The $18 \mathrm{~S}$ rDNA probe was obtained from genomic DNA of Prochilodus argenteus (Prochilodontidae) by PCR (Hatanaka and Galetti, 2004) using NS1 (5'-GTAGTCATATGCTTGTCTC3') and NS8 (5'-TCCGCAGGTTCACCTACGGA-3') primers (White et al., 1990). The probe was indirectly labeled via nick translation, using biotinylated adenine (14dATP-biotin; Invitrogen) and then detected by avidin-FITC (conjugated fluorescein isothiocyanate-avidin; Sigma).

The heterochromatin distribution was analyzed by C-banding (Sumner, 1972). GCand AT-rich chromosomal regions were visualized by fluorochrome staining, using chromomycin $\mathrm{A}_{3}\left(\mathrm{CMA}_{3}\right)$ and DAPI, respectively (Schweizer, 1980).

The chromosomal analyses were carried out on an epifluorescence microscope Olympus BX51 and the micrographs were obtained using the Image Pro-Plus 6.1 software (Media Cybernetics).

\section{RESULTS}

Regardless of the collection site, the modal diploid number observed in $H$. aff. unae was $2 \mathrm{n}=76$. However, interpopulation differences with exclusive karyotype formulae 
were detected for each locality, as follows: $12 \mathrm{~m}+16 \mathrm{sm}+48 \mathrm{st} / \mathrm{a}(\mathrm{FN}=104)$ for population $\mathrm{A}$, $12 \mathrm{~m}+20 \mathrm{sm}+44 \mathrm{st} / \mathrm{a}(\mathrm{FN}=108)$ for population $\mathrm{B}, 10 \mathrm{~m}+14 \mathrm{sm}+52 \mathrm{st} / \mathrm{a}(\mathrm{FN}=100)$ for population $\mathrm{C}$, and $10 \mathrm{~m}+20 \mathrm{sm}+46 \mathrm{st} / \mathrm{a}(\mathrm{FN}=106)$ for population $\mathrm{D}$ (Figure 2).

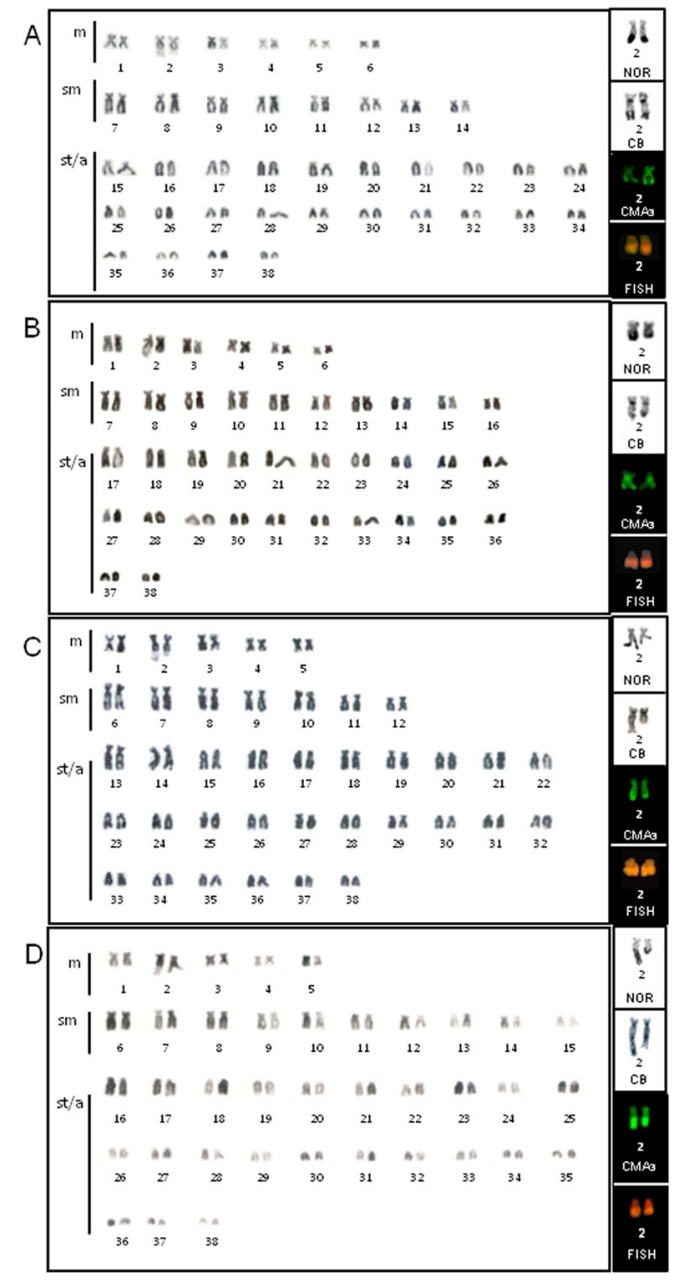

Figure 2. Karyotypes of Hypostomus aff. unae populations. (A) Contas, (B) Preto do Costa, (C) Oricó, and (D) Preto do Criciúma Rivers. Close-up of the NOR-bearing pairs after silver nitrate staining, C-banding, $\mathrm{CMA}_{3}$ staining and $18 \mathrm{~S}$ rDNA FISH. Notice the absence of NOR-associated heterochromatin in C.

Heteromorphic secondary constrictions located at the terminal position on the 2nd metacentric pair and equivalent to NORs were visualized in all specimens (Figure 2, close-up). The active rDNA sites detected by silver nitrate were confirmed by FISH using $18 \mathrm{~S}$ rDNA probes, characterizing a single-NOR system. Similarly to secondary constrictions and Ag-NORs, a size heteromorphism of ribosomal cistrons between homologues was also observed by FISH (Figure 2, close-up).

Besides centromeric heterochromatin, all populations presented conspicuous interstitial and/or terminal C-bands in several acrocentric chromosomes (Figure 3). However, the dis- 
tribution of heterochromatic regions was specific for each collection site, as described below.

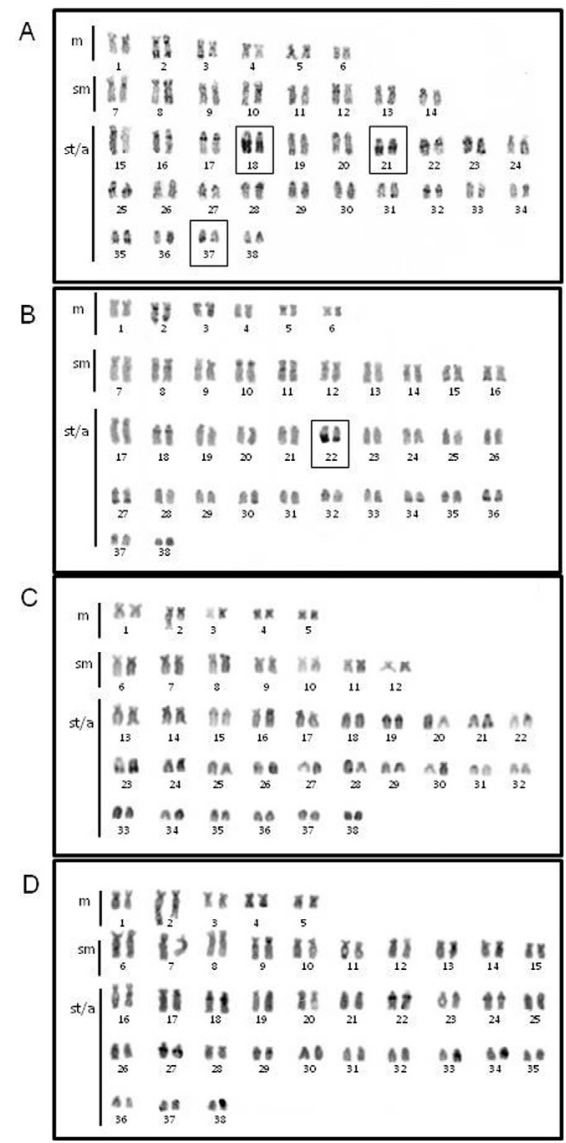

Figure 3. Karyotypes of Hypostomus aff. unae after C-banding in populations A, B, C, and D. The chromosomal pairs bearing heteromorphic heterochromatin are highlighted in A and B.

Population A differs from the others by presenting evident C-bands and a large number of chromosomes bearing heteromorphic blocks (pairs 18, 21 and 37) (Figure 3A). Population $\mathrm{B}$ was characterized by a single noticeable pair with heteromorphic heterochromatin (pair 22) (Figure 3B). On the other hand, heterochromatin differences between homologues were absent in populations $\mathrm{C}$ and $\mathrm{D}$ (Figure $3 \mathrm{C}$ and $\mathrm{D}$, respectively). All specimens, excepting those from population C, showed NOR-associated heterochromatin.

Base-specific fluorochrome staining revealed a single chromosomal pair bearing $\mathrm{CMA}_{3}^{+} / \mathrm{DAPI}^{-}$signals coincident to NORs, indicating that this region is GC-rich (Figure 4). Furthermore, several AT-rich sites $\left(\mathrm{DAPI}^{+}\right)$were detected in the four populations, mainly distributed over interstitial and terminal regions of acrocentric chromosomes (Figure 5).

Based on the cytogenetic methodologies applied in the present study, there is no evidence of heteromorphic sex chromosomes in $H$. aff. unae. 

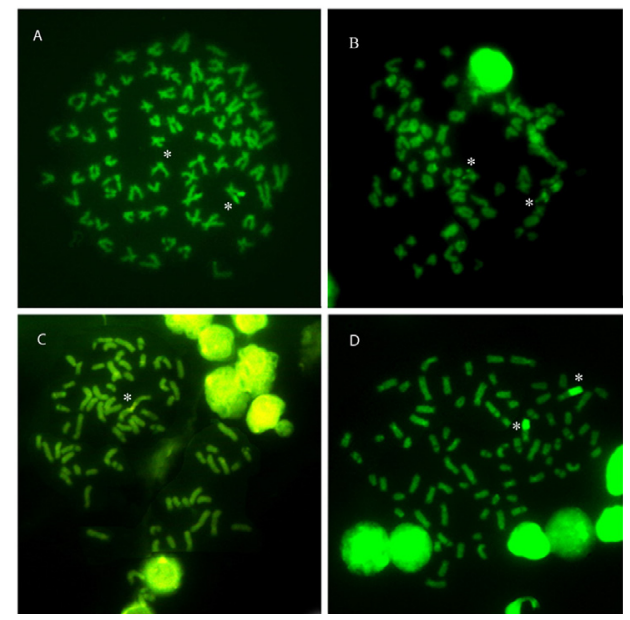

Figure 4. Metaphases of Hypostomus aff. unae from populations A, B, C, and $\mathbf{D}$ after $\mathrm{CMA}_{3}$ staining. The asterisks indicate the NOR-bearing pair.
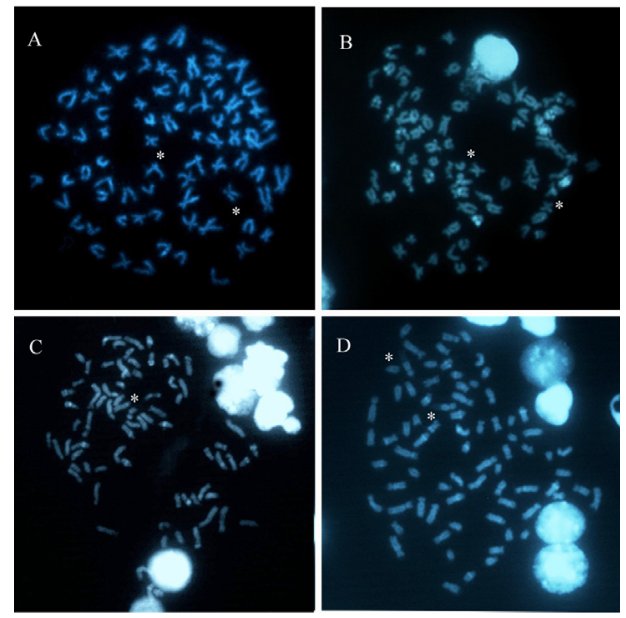

Figure 5. Metaphases of Hypostomus aff. unae from populations A, B, C, and D after DAPI staining, showing several chromosomes bearing positively stained AT-rich regions. The asterisks indicate the NOR-bearing pair.

\section{DISCUSSION}

So far, cytogenetic reports are available for 31 of the 130 recognized Hypostomus species, including the present study (Table 1). Based on these data, $2 n=76$ and $2 n=72$ are the most frequent condition in this genus, representing $25.8 \%$ of all analyzed species each, followed by $2 \mathrm{n}=74(12.9 \%)$ and $2 \mathrm{n}=68(9.6 \%)$.

Nevertheless, comparative analyses with related basal groups show $2 n=54$ to be the plesiomorphic diploid number in Loricariidae (Artoni and Bertollo, 2001). Although shared by several subfamilies, this condition has been reported in a single Hypostomus species and a 


\section{Table 1. Cytogenetic data in Hypostomus species.}

\begin{tabular}{|c|c|c|c|c|c|c|}
\hline Species & Locality & $2 n$ & Chromosomal formula & $\mathrm{B}$ & Sex system & Ref. \\
\hline \multicolumn{7}{|l|}{ Hypostomus } \\
\hline H. affinis & Jacuí Stream (SP) & 66 & $14 m+14 s m+12 s t+26 a$ & - & - & 10 \\
\hline H. ancistroides & Tributaries of Tibagi River (PR) & 68 & $16 \mathrm{~m}+18 \mathrm{sm}+34 \mathrm{st} / \mathrm{a}$ & - & - & 3 \\
\hline H. ancistroides & - & 68 & $10 m+26 s m+32 s t / a$ & - & - & 13 \\
\hline H. ancistroides & Mogi-Guaçu River (SP) & 68 & $16 \mathrm{~m}+18 \mathrm{sm}+34 \mathrm{st} / \mathrm{a}$ & - & - & 3 \\
\hline H. ancistroides & Araquá River (SP) & 68 & $18 \mathrm{~m}+10 \mathrm{sm}+12 \mathrm{st}+28 \mathrm{a}$ & - & - & 1 \\
\hline H. ancistroides & - & 68 & $\begin{array}{l}10 \mathrm{~m}+27 \mathrm{sm}+31 \mathrm{st} / \mathrm{a}(\mathrm{M}) \\
10 \mathrm{~m}+28 \mathrm{sm}+30 \mathrm{st} / \mathrm{a}(\mathrm{F})\end{array}$ & - & $\mathrm{XX} / \mathrm{XY}$ & 11 \\
\hline H. albopunctatus & Mogi-Guaçu River (SP) & 74 & $10 \mathrm{~m}+20 \mathrm{sm}+44 \mathrm{st} / \mathrm{a}$ & - & - & 3 \\
\hline H. albopunctatus & Piracicaba River (SP) & 74 & $10 \mathrm{~m}+20 \mathrm{sm}+44 \mathrm{st} / \mathrm{a}$ & - & - & 7 \\
\hline H. aff. auroguttatus & Mogi-Guaçu River (SP) & 76 & $8 \mathrm{~m}+30 \mathrm{sm}+38 \mathrm{st} / \mathrm{a}$ & - & - & 3 \\
\hline H. emarginatus & Araguaia River (MT) & 52 & $16 \mathrm{~m}+30 \mathrm{sm}+6 \mathrm{st} / \mathrm{a}$ & - & - & 6 \\
\hline H. goyazensis & Vermelho River (GO) & 72 & $10 m+16 s m+10 s t+36 a$ & - & - & 1 \\
\hline H. macrops & - & 68 & $10 \mathrm{~m}+14 \mathrm{sm}+44 \mathrm{st} / \mathrm{a}$ & - & - & 11 \\
\hline H. paulinus & - & 74 & $10 \mathrm{~m}+20 \mathrm{sm}+44 \mathrm{st} / \mathrm{a}$ & - & - & 11 \\
\hline H. paulinus & Três Bocas Stream & 76 & $6 \mathrm{~m}+16 \mathrm{sm}+54 \mathrm{st} / \mathrm{a}$ & - & - & 13 \\
\hline H. plecostomus & - & 54 & $24 \mathrm{~m} / \mathrm{sm}+12 \mathrm{st}+18 \mathrm{a}$ & - & - & 12 \\
\hline H. regani & Mogi-Guaçu River (SP) & 72 & $10 \mathrm{~m}+20 \mathrm{sm}+42 \mathrm{st} / \mathrm{a}$ & - & - & 3 \\
\hline H. regani & Araquá River (SP) & 72 & $12 \mathrm{~m}+18 \mathrm{sm}+26 \mathrm{st}+16 \mathrm{a}$ & - & - & 1 \\
\hline H. regani & Jacutinga Stream (PR) & 72 & $10 \mathrm{~m}+18 \mathrm{sm}+44 \mathrm{st} / \mathrm{a}$ & - & - & 13 \\
\hline H. regani & Piumhi - São Francisco River (MG) & 72 & $8 m+16 s m+20 s t+28 a$ & - & - & 15 \\
\hline H. strigaticeps & $\begin{array}{l}\text { Três Boca Stream, Jacutinga } \\
\text { and Taquari River (PR) }\end{array}$ & 72 & $10 \mathrm{~m}+16 \mathrm{sm}+46 \mathrm{st} / \mathrm{a}$ & - & - & 13 \\
\hline H. strigaticeps & Mogi-Guaçu River (SP) & 74 & $8 m+4 s m+62 s t / a$ & - & - & 11 \\
\hline Hypostomus sp 3- & Salobrinha Stream (MS) & 82 & $6 \mathrm{~m}+12 \mathrm{sm}+64 \mathrm{st} / \mathrm{a}$ & $1-2$ & - & 8 \\
\hline Ribeirão Salobrinha & & 83 & $6 \mathrm{~m}+12 \mathrm{sm}+65 \mathrm{st} / \mathrm{a}$ & & & \\
\hline NUP 4247 & & 84 & $6 \mathrm{~m}+12 \mathrm{sm}+66 \mathrm{st} / \mathrm{a}$ & & & \\
\hline $\begin{array}{l}\text { Hypostomus sp 2-Rio } \\
\text { Perdido NUP } 4249\end{array}$ & Perdido River (MS) & 84 & $6 \mathrm{~m}+16 \mathrm{sm}+62 \mathrm{st} / \mathrm{a}$ & - & - & 8 \\
\hline Hypostomus sp 1 & Paranapanema River (SP) & 64 & - & - & - & 9 \\
\hline Hypostomus sp 1a & Patos Stream (MG) & 76 & $6 m+8 s m+16 s t+46 a$ & - & - & 15 \\
\hline Hypostomus sp $1 \mathrm{~b}$ & Araras Stream (MG) & 76 & $6 m+8 s m+16 s t+46 a$ & - & - & 15 \\
\hline Hypostomus sp 2 & Araras Stream (MG) & 74 & $10 \mathrm{~m}+6 \mathrm{sm}+16 \mathrm{st}+42 \mathrm{a}$ & - & - & 15 \\
\hline Hypostomus sp 2 & Jacutinga Stream (SP) & 68 & - & - & - & 9 \\
\hline Hypostomus sp 2 & Alambari Stream (SP) & 68 & - & - & - & 9 \\
\hline Hypostomus sp 3 & Quinta Stream (SP) & 72 & - & - & - & 9 \\
\hline Hypostomus sp 3 & Edgardia Stream (SP) & 72 & - & - & - & 9 \\
\hline Hypostomus sp 3 & Paranapanema River (SP) & 72 & - & - & - & 9 \\
\hline Hypostomus sp 4 & Hortelã Stream (SP) & 76 & - & - & - & 9 \\
\hline Hypostomus sp 4 & Paranapanema River (SP) & 76 & - & - & - & 9 \\
\hline Hypostomus sp $A$ & Rincão River (SP) & 70 & $18 \mathrm{~m}+14 \mathrm{sm}+38 \mathrm{st} / \mathrm{a}$ & - & - & 3 \\
\hline Hypostomus $\mathrm{sp} B$ & Mogi-Guaçu River (SP) & 72 & $12 \mathrm{~m}+18 \mathrm{sm}+42 \mathrm{st} / \mathrm{a}$ & - & - & 3 \\
\hline Hypostomus sp $B$ & Mogi-Guaçu River (SP) & 72 & $13 \mathrm{~m}+18 \mathrm{sm}+41 \mathrm{st} / \mathrm{a}$ & - & - & 5 \\
\hline Hypostomus sp C & Mogi-Guaçu River (SP) & 72 & $10 \mathrm{~m}+18 \mathrm{sm}+44 \mathrm{st} / \mathrm{a}$ & - & - & 3 \\
\hline Hypnstomus sp DI & Mogi-Guaçu River (SP) & 72 & $10 \mathrm{~m}+26 \mathrm{sm}+36 \mathrm{st} / \mathrm{a}$ & - & - & 3 \\
\hline Hypostomus sp D2 & Mogi-Guaçu River (SP) & 72 & $14 \mathrm{~m}+20 \mathrm{sm}+38 \mathrm{st} / \mathrm{a}$ & - & - & 3 \\
\hline Hypostomus sp $E$ & Mogi-Guaçu River (SP) & 80 & $8 m+16 s m+56 s t / a$ & - & - & 3 \\
\hline Hypostomus sp $F$ & São Francisco River (MG) & 76 & $10 \mathrm{~m}+16 \mathrm{sm}+50 \mathrm{st} / \mathrm{a}$ & - & - & 2 \\
\hline Hypostomus sp $F$ & São Francisco River (MG) & 75 & $10 \mathrm{~m}+17 \mathrm{sm}+48 \mathrm{st} / \mathrm{a}$ & - & - & 5 \\
\hline Hypostomus sp $G$ & Araguaia River (MT) & 64 & $14 \mathrm{~m}+24 \mathrm{sm}+26 \mathrm{st} / \mathrm{a}(\mathrm{M})$ & - & $\mathrm{ZZ/ZW}$ & 4 \\
\hline & & & $15 \mathrm{~m}+24 \mathrm{sm}+25 \mathrm{st} / \mathrm{a}(\mathrm{F})$ & & & \\
\hline H. nigromaculatus & Três Bocas and Apertados Stream (PR) & 76 & $6 \mathrm{~m}+20 \mathrm{sm}+50 \mathrm{st} / \mathrm{a}$ & - & - & 14 \\
\hline H. nigromaculatus & Mogi-Guaçu River (SP) & 76 & $8 \mathrm{~m}+20 \mathrm{sm}+48 \mathrm{st} / \mathrm{a}$ & - & - & 14 \\
\hline Hypostomus sp Xingu-1 & Xingu River (PR) & 64 & $16 \mathrm{~m}+16 \mathrm{sm}+32 \mathrm{st} / \mathrm{a}$ & - & - & 16 \\
\hline Hypostomus sp Xingu-2 & Xingu River (PR) & 66 & $18 \mathrm{~m}+14 \mathrm{sm}+34 \mathrm{st} / \mathrm{a}$ & - & - & 16 \\
\hline Hypostomus $\mathrm{sp}$ Xingu-3 & Xingu River (PR) & 64 & $15 \mathrm{~m}+23 \mathrm{sm}+26 \mathrm{st} / \mathrm{a}$ & 1 & - & 16 \\
\hline & & 65 & $15 \mathrm{~m}+23 \mathrm{sm}+27 \mathrm{st} / \mathrm{a}$ & & & \\
\hline$H$. aff. unae & Contas River (BA) & 76 & $12 \mathrm{~m}+16 \mathrm{sm}+48 \mathrm{st} / \mathrm{a}$ & - & - & 17 \\
\hline H. aff. unae & Preto do Costa River (BA) & 76 & $12 \mathrm{~m}+20 \mathrm{sm}+44 \mathrm{st} / \mathrm{a}$ & - & - & 17 \\
\hline H. aff. unae & Oricó River (BA) & 76 & $10 \mathrm{~m}+14 \mathrm{sm}+52 \mathrm{st} / \mathrm{a}$ & - & - & 17 \\
\hline H. aff. unae & Preto do Criciuma River (BA) & 76 & $10 \mathrm{~m}+20 \mathrm{sm}+46 \mathrm{st} / \mathrm{a}$ & - & - & 17 \\
\hline
\end{tabular}

$1=$ Alves et al. (2006); 2 = Artoni (1996); $3=$ Artoni and Bertollo (1996); 4 = Artoni et al. (1998); $5=$ Artoni and Bertollo (1999); $6=$ Artoni and Bertollo (2001); $7=$ Camilo (2004); $8=$ Cereali et al. (2008); $9=$ Fenerich and Oliveira (2004); $10=$ Kavalco et al. (2005); $11=$ Michelle et al. (1977); 12 = Muramoto et al. (1968); 13 $=$ Rubert (2007); $14=$ Rubert et al. (2008); $15=$ Mendes-Neto (2008); $16=$ Milhomem et al. (2010); $17=$ This study. $\mathrm{m}=$ metacentric; $\mathrm{sm}=$ submetacentric; $\mathrm{st}=$ subtelocentric; $\mathrm{a}=$ acrocentric. 
few other Hypostominae (Artoni and Bertollo, 2001; Alves et al., 2005). Instead, the subfamily Hypostominae is characterized by a remarkable diversity of karyotypic forms, with $2 \mathrm{n}$ ranging from 34 (Oliveira et al., 2009b) to 84 (Cereali et al., 2008).

In general, loricariids exhibit a strong correlation between high numbers of meta/ submetacentric chromosomes and low diploid number (i.e., the higher the $2 \mathrm{n}$, the higher the frequency of subtelo/acrocentric chromosomes). For instance, a karyotype formula of $32 \mathrm{~m} /$ $\mathrm{sm}+2 \mathrm{st}$ is reported for Ancistrus sp Purus $(2 \mathrm{n}=34)$ (Oliveira et al., 2009b) while Upsilodus sp $(2 \mathrm{n}=96)$ presents $16 \mathrm{~m}+8 \mathrm{sm}+72 \mathrm{a}($ Kavalco et al., 2005). This pattern indicates that centric fissions have played a major role in the karyotypic evolution of this family (Artoni and Bertollo, 2001 ) and can be inferred to explain the derived karyotype observed in $H$. aff. unae ( $2 n=76$ and the presence of several st/a pairs).

However, other chromosomal rearrangements can also be identified in the genus Hypostomus. As observed in the present study, the maintenance of $2 \mathrm{n}=76$ with distinctive karyotype formulae in the four analyzed populations indicates that pericentric inversions are involved as well. Similarly, variation in karyotype formulae has been identified among several populations of Hypostomus (Table 1). Nonetheless, a misidentification of close chromosomal types because of their reduced size and/or differential chromatin condensation might interfere with the precision of karyotypic analyses. To minimize putative technical artifacts, we divided the chromosomal pairs of each population into bi-armed and one-armed groups $(\mathrm{m} / \mathrm{sm}$ and st/a, respectively). Nevertheless, the karyotypic divergence among the studied populations remained evident (Table 2).

Table 2. Karyotype formulae of Hypostomus aff. unae populations divided into $\mathrm{m} / \mathrm{sm}$ and st/a chromosomal types.

\begin{tabular}{lc}
\hline Population & Karyotype formula \\
\hline A & $28 \mathrm{~m} / \mathrm{sm}+48 \mathrm{st} / \mathrm{a}$ \\
B & $32 \mathrm{~m} / \mathrm{sm}+44 \mathrm{st} / \mathrm{a}$ \\
C & $24 \mathrm{~m} / \mathrm{sm}+52 \mathrm{st} / \mathrm{a}$ \\
D & $30 \mathrm{~m} / \mathrm{sm}+46 \mathrm{st} / \mathrm{a}$ \\
\hline
\end{tabular}

$\mathrm{m}=$ metacentric $; \mathrm{sm}=$ submetacentric; $\mathrm{st}=$ subtelocentric; $\mathrm{a}=$ acrocentric.

Terminal NORs on long arms of a single chromosomal pair, a basal feature within loricariids (Kavalco et al., 2005), were observed in $H$. aff. unae. Moreover, an NOR size heteromorphism was usually observed between homologs in all samples, although more evident in population D. Polymorphic conditions related to differences in NOR size between chromosomes are frequent in fish species bearing single NORs (Artoni and Bertollo, 2001; Affonso and Galetti Jr., 2005).

FISH using 18S rDNA probes confirmed both the location of major ribosomal genes and the heteromorphic NOR size between homologues. Thus, the size differences in rDNA clusters are indeed structural and not just transcriptional as assumed after silver nitrate staining (Figure 2, close-up) and are likely to result from duplications/deletions or unequal crossovers (Affonso and Galetti Jr., 2005).

A co-localization of NORs and heterochromatin is commonly reported for Hypostomus (Rubert et al., 2008). However, this correspondence is not a ubiquitous condition inasmuch as it is absent in some loricariids such as Upsilodus sp, Neoplecostomus microps Steindachner, 1877 (Kavalco et al., 2005) and population C of $H$. aff. unae analyzed in the 
present study. However, the latter also presented GC-rich NORs as shown by $\mathrm{CMA}_{3}{ }^{+}$signals, following the general pattern among Hypostominae (Rubert et al., 2008).

Heterochromatic blocks distributed at interstitial regions are considered to be an ancestral condition in Loricariidae and frequently observed in this family and in the closely related Callichthyidae fish (Frehner et al., 2004). In the subfamily Hypostominae, conspicuous heterochromatic segments at interstitial regions of acrocentric chromosomes are regarded as the common pattern for species with high diploid numbers (Artoni and Bertollo, 2001). Nevertheless, the populations $\mathrm{A}, \mathrm{B}$, and $\mathrm{C}$ of $H$. aff unae, although presenting $2 \mathrm{n}=76$, do not fit this hypothetical pattern since they bear large terminal heterochromatin blocks of acrocentric chromosomes. This evidence suggests that heterochromatin distribution within Hypostomus is more complex than previously thought.

The studied specimens also presented an equilocal distribution of interstitial heterochromatin, more evident in population $\mathrm{D}$. These $\mathrm{C}$ bands, located equidistantly throughout acrocentric chromosomes, are in accordance with the model of heterochromatin distribution proposed by Schweizer and Loidl (1987) and seem to be a common feature of Loricariidae species (Frehner et al., 2004).

Moreover, the positional differences of C-bands among the studied populations from terminal to interstitial location might be explained by paracentric inversions or transpositions. Afterwards, these segments could have been amplified and/or accumulated and evolved independently in each population.

$\mathrm{DAPI}^{+}$(AT-rich) signals are rarely found in fish but detected in a few Hypostomus species (Artoni and Bertollo, 1999) including populations A, C and D of $H$. aff. unae (Figure 5A, C and D). The equivalent location of AT-rich blocks on several chromosomal pairs points towards a common origin of this segment that was distributed to equilocal sites by heterochromatin dispersion within a specific chromosomal group (Schweizer and Loidl, 1987). Similar hypotheses have been proposed to explain the preferential pattern of heterochromatin distribution in some fish species with derived karyotypes (Mantovani et al., 2000; Affonso and Galetti Jr., 2005).

AT-richness is usually associated with a pronounced DNA curvature and subsequent chromosomal stability, as reported in some fish species like Salmo trutta Linnaeus, 1758 (Caputo et al., 2009). On the contrary, several AT-rich segments were coupled with chromosomal variation in the genome of $H$. aff. unae suggesting that such correlation remains to be confirmed in Neotropical fish species. In specimens from population $\mathrm{B}$, equally $\mathrm{CMA}_{3}^{+}$and $\mathrm{DAPI}^{+}$marks were characterized, suggesting that GC and AT-rich regions are interspersed, although visualized as a single overlapped signal (Figures 4B and 5B).

Dispersal constraints might favor the fixation of chromosomal rearrangements by genetic drift or differential selective pressures (if some adaptive value in the chromosomal structure is present) leading to interpopulation divergence and high endemism (Oliveira et al., 2009a). Because of their non-migratory benthic behavior, very little gene flow between populations of Hypostominae would be expected (Zawadzki et al., 2005). In fact, relatively low levels of genetic variability and significant population structure assessed by allozyme and DNA markers have been reported for different species of Hypostomus that could be related to the sedentary habit of these fish (Zawadzki et al., 2005).

The Contas River basin is divided into three physiographic regions (Upper, Middle and Lower), encompassing distinct landscapes: semiarid biome, transition zones and Atlantic forest (Pamponet et al., 2008). All sampling sites of $H$. aff. unae belong to the Middle Contas 
sub-basin but they can be readily distinguished by environmental/physical features: the main river channel (site A) is a highly damaged area, affected upstream by the Pedras dam and industrial and domestic sewage from the city of Jequié (Pamponet et al., 2008); site B is a narrow river located on a transition zone between semiarid and tropical climates; site $\mathrm{C}$ is a comparatively large, fast flowing river located in a typical Atlantic forest region, and site D is a headwater stream in Atlantic forest, with several small waterfalls and separated from the Contas River (6 km apart) by a reservoir.

Thus, the cytogenetic differences among the studied populations might be associated with both the low vagility of Hypostomus and the environmental particularities of each site but not the geographical distance per se. Similar hypotheses were inferred to explain genetic differences in other fish species along the Middle Contas sub-basin (Pamponet et al., 2008).

Considering that Hypostomus is a taxonomically controversial group, the present results may actually be related to the occurrence of a cryptic species along the Contas river basin, as commonly observed in other Hypostomus (Milhomem et al., 2010).

Finally, in spite of their importance to our understanding of karyotypic evolution, studies focusing on heterochromatin are scarce in Siluriformes, as well as in many Neotropical fish species from isolated Brazilian coastal basins. The present study represents an effort to change this scenario, providing the first cytogenetic report in Loricariidae from a northeastern South America basin with identification of distinctive evolutionary units of Hypostomus aff. unae.

\section{ACKNOWLEDGMENTS}

The authors are grateful to Cláudio Henrique Zawadzki (UEM-NUPELIA) for identifying the specimens, Leandro Sousa (MZUSP) and Priscila Camelier de Assis Cardoso (UFBA) for the map and CNPq and FAPESB for financial support.

\section{REFERENCES}

Affonso PR and Galetti PM Jr (2005). Chromosomal diversification of reef fishes from genus Centropyge (Perciformes, Pomacanthidae). Genetica 123: 227-233.

Allendorf FR and Luikart G (2007). Conservation and the Genetics of Populations. Blackwell Publishing, Oxford.

Alves AL, Oliveira C and Foresti F (2005). Comparative cytogenetic analysis of eleven species of subfamilies Neoplecostominae and Hypostominae (Siluriformes: Loricariidae). Genetica 124: 127-136.

Alves AL, Oliveira C, Nirchio M, Granado A, et al. (2006). Karyotypic relationships among the tribes of Hypostominae (Siluriformes: Loricariidae) with description of XO sex chromosome system in a Neotropical fish species. Genetica 128: 1-9.

Artoni RF (1996). Estudos Citogenéticos na Família Loricariidae com Ênfase no Gênero Hypostomus (Lacépède, 1803) (Pisces, Siluriformes). Master's thesis, Universidade Federal de São Carlos, São Carlos.

Artoni RF and Bertollo LAC (1996). Cytogenetic studies on Hypostominae (Pisces, Siluriformes, Loricariidae). Considerations on karyotype evolution in the genus Hypostomus. Caryologia 49: 81-90.

Artoni RF and Bertollo LA (1999). Nature and distribution of constitutive heterochromatin in fishes, genus Hypostomus (Loricariidae). Genetica 106: 209-214.

Artoni RF and Bertollo LA (2001). Trends in the karyotype evolution of Loricariidae fish (Siluriformes). Hereditas 134: 201-210.

Artoni RF, Venere PC and Bertollo LAC (1998). A heteromorphic ZZ/ZW sex chromosome system in fish, genus Hypostomus (Loricariidae). Cytologia 63: 421-425.

Bertollo LAC, Takahashi CS and Moreira-Filho O (1978). Cytotaxonomic considerations on Hoplias lacerdae (Pisces, Erythrinidae). Rev. Bras. Genet. 1: 103-120.

Camilo FM (2004). Estudos Citogenéticos em Algumas Espécies de Peixes da Família Loricariidae Pertencentes à Bacia do Rio Piracicaba - SP. Master's thesis, Universidade Federal de São Carlos, São Carlos.

Caputo V, Giovannotti M, Nisi CP, Splendiani A, et al. (2009). Chromosomal study of native and hatchery trouts from 
Italy (Salmo trutta complex, Salmonidae): conventional and FISH analysis. Cytogenet. Genome Res. 124: 51-62.

Cereali SS, Pomini E, Rosa R, Zawadzki CH, et al. (2008). Karyotype description of two species of Hypostomus (Siluriformes, Loricariidae) of the Planalto da Bodoquena, Brazil. Genet. Mol. Res. 7: 583-591.

Fenerich PC, Foresti F and Oliveira C (2004). Nuclear DNA content in 20 species of Siluriformes (Teleostei: Ostariophysi) from the Neotropical region. Genet. Mol. Biol. 27: 350-354.

Ferraris CJ Jr (2007). Checklist of Catfishes, Recent and Fossil (Osteichthyes: Siluriformes), and Catalogue of Siluriform Primary Types. Magnolia Press, New Zealand.

Frehner KK, Pazza R, Bertollo LA and Moreira-Filho O (2004). Heterochromatin characterization of four fish species of the family Loricariidae (Siluriformes). Hereditas 141: 237-242.

Hatanaka T and Galetti PM (2004). Mapping of the 18S and 5S ribosomal RNA genes in the fish Prochilodus argenteus Agassiz, 1829 (Characiformes, Prochilodontidae). Genetica 122: 239-244.

Howell WM and Black DA (1980). Controlled silver-staining of nucleolus organizer regions with a protective colloidal developer: a 1-step method. Experientia 36: 1014-1015.

Jacobina U, Affonso PRAM, Carneiro PLS and Dergam JA (2009). Biogeography and comparative cytogenetics between two populations of Hoplias malabaricus (Bloch, 1794) (Ostariophysi: Erythrinidae) from coastal basins in the State of Bahia, Brazil. Neotrop. Ichthyol. 7: 617-622.

Kavalco KF, Pazza R, Bertollo LA and Moreira-Filho O (2005). Karyotypic diversity and evolution of Loricariidae (Pisces, Siluriformes). Heredity 94: 180-186.

Mantovani M, Abel LDS, Mestriner CA and Moreira-Filho O (2000). Accentuated polymorphism of heterochromatin and nucleolar organizer regions in Astyanax scabripinnis (Pisces, Characidae): tools for understanding karyotypic evolution. Genetica 109: 161-168.

Mendes-Neto EO (2008). Estudos Citogenéticos em Algumas Espécies de Loricariidae (Teleostei, Siluriformes) da Região de Transposição do Rio Piumhi para o Rio São Francisco. Master's thesis, Universidade Federal de São Carlos, São Carlos.

Michelle JL, Takahashi CS and Ferrari I (1977). Karyotypic study of some species of the family Loricariidae (Pisces). Cytologia 42: 539-546.

Milhomem SSR, Castro RR, Nagamachi CY, Souza ACP, et al. (2010). Different cytotypes in fishes of the genus Hypostomus Lacépède, 1803 (Siluriformes: Loricariidae) from Xingu river (Amazon region, Brazil). Comparat. Cytogenet. 4: 45-54.

Molina WF (2001). An alternative method for mitotic stimulation in fish cytogenetics. Chromosome Sci. 5: 149-152.

Muramoto JI, Ohno S and Atkin NB (1968). On the diploid state of the fish order Ostariophysi. Chromosoma 24: 59-66.

Nelson JS (2006). Fishes of the World. Willey, New York.

Nirchio M and Oliveira C (2006). Citogenética de Peces. Universidad de Oriente, Cumaná.

Oliveira C, Foresti F and Hilsdorf AW (2009a). Genetics of Neotropical fish: from chromosomes to populations. Fish Physiol. Biochem. 35: 81-100.

Oliveira RR, Feldberg E, Anjos MB and Zuanon J (2009b). Mechanisms of chromosomal evolution and its possible relation to natural history characteristics in Ancistrus catfishes (Siluriformes: Loricariidae). J. Fish Biol. 75: 2209-2225.

Pamponet VCC, Carneiro PLS, Affonso PRAM, Miranda VS, et al. (2008). A multi-approach analysis of the genetic diversity in populations of Astyanax aff. bimaculatus Linnaeus, 1758 (Teleostei: Characidae) from Northeastern Brazil. Neotrop. Ichthyol. 6: 621-630.

Pinkel D, Straume T and Gray JW (1986). Cytogenetic analysis using quantitative, high-sensitivity, fluorescence hybridization. Proc. Natl. Acad. Sci. U. S. A. 83: 2934-2938.

Rubert M (2007). Estudos Citogenéticos em Diferentes Populações do Gênero Hypostomus (Loricariidae, Hypostominae). Master's thesis, Universidade Estadual de Londrina, Londrina.

Rubert M, Zawadzki CH and Giuliano-Caetano L (2008). Cytogenetic characterization of Hypostomus nigromaculatus (Siluriformes: Loricariidae). Neotrop. Ichthyol. 6: 93-100.

Schweizer D (1980). Simultaneous fluorescent staining of R bands and specific heterochromatic regions (DA-DAPI bands) in human chromosomes. Cytogenet. Cell Genet. 27: 190-193.

Schweizer D and Loidl J (1987). A model for heterochromatin dispersion and the evolution of C-bands patterns. Chromosomes Today 9: 61-74.

Sumner AT (1972). A simple technique for demonstrating centromeric heterochromatin. Exp. Cell Res. 75: 304-306.

White TJ, Bruns T, Lee S and Taylor J (1990). Amplification and Direct Sequencing of Fungal Ribosomal RNA Genes for Phylogenetics. In: PCR Protocols: A Guide to Methods and Applications (Innis M, Gelfand D, Shinsky J and White T, eds.). Academic Press, New York, 315-322.

Zawadzki CH, Renesto E, Reis RE, Moura MO, et al. (2005). Allozyme relationships in hypostomines (Teleostei: Loricariidae) from the Itaipu Reservoir, upper Rio Paraná basin, Brazil. Genetica 123: 271-283.

Zawadzki CH, Weber C and Pavanelli CS (2008). Two new species of Hypostomus Lacépède (Teleostei: Loricariidae) from the upper river Paraná basin, Central Brazil. Neotrop. Ichthyol. 6: 403-412. 